\title{
Study on Estimates of Embodied Carbon of China: Based on Input-Output Analysis
}

\author{
Zhonglin Sheng, Yufei Xin, and Weida He
}

\begin{abstract}
In this paper, we use input-output analysis and commodity exporting data of China during 1999-2012 to conduct an empirical study and calculate carbon embodiments in China's exporting goods. The results show that China has been exporting a large amount of carbon embodiments, and its increase of $\mathrm{CO}_{2}$ emissions has a close relationship with its export and import, among the annual $\mathrm{CO}_{2}$ emissions of China, about $12 \%-24 \%$ were caused by the demands of other countries.
\end{abstract}

Index Terms - Carbon emissions embodied, import, export, China.

\section{INTRODUCTION}

Climate change is one of the most enormous challenges to international community. The extreme weather is rising and has attracted many organizations and researchers [1]. Countries have made efforts to reduce $\mathrm{CO}_{2}$ emissions which are linked to climate change. The Kyoto Protocol set emission reduction goals for "Annex I" parties and most of them are developed countries. But these countries could reduce their national emissions in many ways, such as the relocation of production abroad, import substitution.

As the "world factory", China's current trade structure is relatively extensive and sustainability is also relatively weak. In the meantime, the product structures of exports and imports have great differences [2]. Imported products are mostly high value-added, high-tech, low energy density, low-emission, but export products are mostly high resource and energy inputs, high emission and low value-added. As a result, China has to sustain the growing trade surplus at the expense of domestic energy resources consumption and environmental pollution [3]. For developed countries, they prefer to transfer these production processes with high energy consumption, high pollution and $\mathrm{CO}_{2}$ emissions to China in order to achieve their emission reduction targets [4].

In this paper, we conduct an empirical study and calculates carbon embodiments in China's exporting and imported goods by using input-output method. The results can reflect the impact of China's import and export on the growth of carbon emissions [5]. Based on the analysis, this paper points out the international society should consider both principle of producer responsibility and consumer responsibility in identifying emission responsibilities and emission reduction targets of each country, and Chinese government should make great efforts in improving production technology,

Manuscript received December 24, 2016, revised February 30, 2016.

The authors are with University of Science and Technology Beijing, China (e-mail: sheng075071@gmail.com). reducing the energy consumption intensity embodied in its production, and restricting the exporting of energy-intensive products.

\section{LITERATURE REVIEW}

Currently the national carbon emissions data released by IPCC is based on the Polluters Pays Principle (PPP), which is the principle on how to recognize the specific carbon emissions responsibility of one country. The PPP was firstly proposed by the Environment Committee of Organization for Economic Co-operation and Development (OECD) in 1972, and its core was to require all polluters to pay for their pollution. All along, the international community, especially the OECE countries, adopt the PPP as a fundamental basis for environmental policy [6]. In terms of carbon emissions, it requires producers to pay for all the carbon emission during product process. However, this method only considers the $\mathrm{CO}_{2}$ emissions directly related to each sector within the national boundaries, that is to say, it only reflects its greenhouse gas emissions within the national boundaries, and does not take the embodied carbon transfer aroused by foreign trade into account [7].

As an environmental indicator, embodied carbon is used to describe all the direct and indirect pollution, from upstream to downstream production process. In recent years, many countries have paid more and more attention to embodied carbon. Many studies show that major developed countries in the world are essentially the net importing countries of carbon emissions [8]. In contrast, the net exporter of carbon are mostly developing countries and a few small developed nations which are mainly composed of resource products. Some research show that the total carbon emissions in recent years the total carbon emissions of China are increasing rapidly, part of which is the embodied carbon in international trade.

At present, there are few empirical studies on China's embodied carbon and they are mostly concentrated on the theoretical analysis so the research methods needs further improving [9]. In this study, we focus on empirical models and data, to work out carbon embodiments in China's exporting and imported goods.

\section{Methodology}

\section{A. Input-Output Model}

Input-output analysis is an effective tool to evaluate the resources and pollution embedded into the goods and services from the point of macro scale, and it has been widely 
output can be showed as follows:

$$
X=(I-A)^{-1} y
$$

$X$ is a social gross output column vector. $Y$ is the final product for society column vector. $A$ is the coefficient matrix for production technology, and $I$ is a unit matrix. $(I-A)^{-1}$ is the Leontief inverse matrix, which reflects the direct and indirect input of the final demand in a unit. In an open economy system, $A$ is divided into two parts, $A^{d}$ and $A^{m}$. One is for domestic inputs during usage, the other is for direct consumption coefficient matrix of imported inputs and $A=A^{d}+A^{m}$. They are both important when calculating the embodied carbon emissions in the international trade. The final social demand can also be decomposed into two parts, the domestic consumption demand $y^{d}$ (including the final consumption and capital formation) and export demand $(Z)$. Thus, in an open economic system, when considering the final purpose of demand, the total output of a country should be expressed as:

$$
X^{d}=\left(I-A^{d}\right)^{-1}\left(y^{d}+Z\right)
$$

We set $E=\left\{F_{j}^{d} / X_{j}^{d}\right\}$ as the direct carbon intensity matrix of domestic unit output, and $F_{j}^{d}$ is the total amount of carbon emissions directly generated in the domestic sector $j$ so the domestic embodied carbon emissions $\left(C^{d}\right)$ which could meet the final demands can be showed as:

$$
\begin{aligned}
& c^{d}=E X^{d}=E\left(I-A^{d}\right)^{-1}(y+Z) \\
& =E\left(I-A^{d}\right)^{-1} y^{d}+E\left(I-A^{d}\right)^{-1} Z \\
& =R^{d} y^{d}+R^{d} Z
\end{aligned}
$$

$R^{d}=E\left(I-A^{d}\right)^{-1}$ is expressed as the direct and indirect carbon emissions that meet final demands for units; $R^{d} y^{d}$ represents domestic emissions $\left(C^{d d}\right)$ to meet domestic consumption, and $R^{d} Z$ is domestic exports emissions $\left(C^{d z}\right)$.

However, in order to achieve products and service of final demands, China still needs to import intermediate inputs $\left(A^{m} X^{d}\right)$. Besides, the final consumer products may be imported from abroad $\left(y^{m}\right)$. The China's total imports of goods and services from abroad $(M)$ is

$$
\begin{aligned}
& M=A^{m} X^{d}+y^{m}= \\
& A^{m}\left(I-A^{d}\right)^{-1}\left(y^{d}+Z\right)
\end{aligned}
$$

And the total carbon emissions from China's imported products or services in foreign countries is as follows:

$$
\begin{aligned}
& C^{t m}=R^{m} M=R^{m} A^{m}\left(I-A^{d}\right)^{-1}\left(y^{d}+Z\right) \\
& +R^{m} y^{m}=R^{m} A^{m}\left(I-A^{d}\right)^{-1} y^{d}+ \\
& R^{m} A^{m}\left(I-A^{d}\right)^{-1} Z+R^{m} y^{m}
\end{aligned}
$$

$R^{m}$ shows the embodied carbon including direct and indirect carbon emissions from aboard, while $R^{m} A^{m}\left(I-A^{d}\right)^{-1} y^{d}$ is imported carbon emissions to obtain domestic consumption. $R^{m} A^{m}\left(I-A^{d}\right)^{-1} Z$ is imported carbon emissions for export demands, that is, import and re-export emissions $\left(C^{m z}\right)$. The emissions of imported consumer goods for final consumption is $R^{m} y^{m}$.

In order to meet the final demands of China, the total carbon emissions $\left(C^{t}\right)$, including domestic emissions $\left(C^{d}\right)$ and the total import emissions $\left(C^{t m}\right)$, can be showed as:

$$
\begin{aligned}
& C^{d}=C^{d}+C^{t m}=R^{d} y^{d}+R^{d} Z+ \\
& R^{m} A^{m}\left(I-A^{d}\right)^{-1} Z+R^{m} y^{m}= \\
& {\left[R^{d}+R^{m} A^{m}\left(I-A^{d}\right)^{-1}\right]\left(y^{d}+Z\right)} \\
& +R^{m} y^{m}
\end{aligned}
$$

Considering the import and re-export emissions, the total embodied carbon of China's total export is:

$$
C^{t z}=R^{d} Z+R^{m} A^{m}\left(I-A^{d}\right)^{-1} Z
$$

Moreover, taking off the import and re-export emission, the actual import embodied carbon in order to meet domestic consumers' demands is:

$$
C^{m d}=R^{m} A^{m}\left(I-A^{d}\right)^{-1} y^{d}+R^{m} y^{m}
$$

As a result, the net balance of embodied carbon emissions in Chinese import and export is as follows:

$$
\begin{aligned}
& C^{b}=C^{t z}-C^{t m}=C^{d z}-C^{m d} \\
& =R^{d} Z-R^{m} A^{m}\left(I-A^{d}\right)^{-1} y^{d}
\end{aligned}
$$

\section{B. Data}

We use the data of the import and export (including import and export of goods and services) are directly from the Chinese Input-output Table (Year of 1999, 2002, 2007, 2012). 
TABLE I: 2012 CHINESE AUTHORITIES EMBODIED CARBON EMISSIONS (MTC)

\begin{tabular}{|c|c|c|c|c|c|c|c|c|}
\hline Departments & $\begin{array}{l}\text { Aggregate } \\
\text { demand } \\
\text { emissions }\end{array}$ & $\begin{array}{c}\text { Direct } \\
\text { emissions }\end{array}$ & $\begin{array}{l}\text { Domestic } \\
\text { emissions }\end{array}$ & $\begin{array}{l}\text { Import } \\
\text { emissions }\end{array}$ & $\begin{array}{l}\text { Actual export } \\
\text { emissions }\end{array}$ & $\begin{array}{l}\text { Aggregate } \\
\text { export } \\
\text { emissions }\end{array}$ & $\begin{array}{c}\text { Domestic } \\
\text { export }\end{array}$ & $\begin{array}{c}\text { Net } \\
\text { export }\end{array}$ \\
\hline Agriculture & 56.54 & 38.13 & 53.65 & 2.89 & 2.52 & 3.53 & 3.16 & 1.64 \\
\hline Coal mining and dressing & 4.38 & 89.78 & 3.58 & 0.80 & 0.53 & 4.16 & 3.89 & 3.36 \\
\hline Petroleum \& gas & 12.64 & 19.25 & 0.90 & 11.74 & 7.56 & 5.60 & 11.41 & -6.15 \\
\hline Metal mining & 13.15 & 2.52 & 2.19 & 10.96 & 6.38 & 5.46 & 0.88 & -5.50 \\
\hline Nonmetal minerals mining & 1.78 & 3.78 & 1.13 & 0.65 & 0.50 & 1.46 & 1.31 & 0.81 \\
\hline Food and tobacco processing & 85.14 & 17.41 & 83.53 & 1.60 & 1.40 & 7.96 & 7.75 & 6.35 \\
\hline Textile industry & 51.31 & 13.77 & 50.03 & 1.28 & 0.57 & 52.12 & 51.41 & 50.84 \\
\hline Clothing, feather and leather & 58.45 & 2.30 & 57.71 & 0.74 & 0.59 & 27.67 & 27.52 & 26.93 \\
\hline $\begin{array}{c}\text { Timber processing and } \\
\text { furniture } \\
\end{array}$ & 23.37 & 2.37 & 22.96 & 0.41 & 0.31 & 14.64 & 14.54 & 14.23 \\
\hline Paper printing & 20.19 & 19.32 & 18.64 & 1.55 & 1.08 & 17.43 & 16.95 & 15.87 \\
\hline $\begin{array}{l}\text { Petroleum, coking and } \\
\text { nuclear fuel processing }\end{array}$ & 25.80 & 395.42 & 16.48 & 9.31 & 6.34 & 22.70 & 19.72 & 13.38 \\
\hline Chemical industry & 130.90 & 131.93 & 104.78 & 26.11 & 16.54 & 92.60 & 83.03 & 66.49 \\
\hline Non-mental mineral products & 18.97 & 102.52 & 17.64 & 1.34 & 1.16 & 21.18 & 21.00 & 19.84 \\
\hline $\begin{array}{c}\text { Metal smelting and rolling } \\
\text { processing }\end{array}$ & 77.98 & 329.78 & 60.66 & 17.32 & 11.11 & 88.86 & 82.65 & 71.54 \\
\hline Metal products & 48.10 & 2.96 & 46.55 & 1.55 & 1.07 & 38.33 & 37.74 & 36.67 \\
\hline $\begin{array}{c}\text { General and special } \\
\text { equipment manufacturing }\end{array}$ & 163.53 & 10.79 & 149.41 & 14.12 & 11.34 & 48.79 & 46.01 & 34.66 \\
\hline $\begin{array}{c}\text { Transportation equipment } \\
\text { manufacturing }\end{array}$ & 112.42 & 6.31 & 107.43 & 4.99 & 4.24 & 22.58 & 21.82 & 17.58 \\
\hline $\begin{array}{c}\text { Electrical machinery and } \\
\text { communication electronics } \\
\text { manufacturing }\end{array}$ & 263.55 & 3.57 & 232.72 & 30.83 & 19.06 & 188.00 & 176.23 & 157.17 \\
\hline $\begin{array}{c}\text { Instrumentation and cultural } \\
\text { office machinery } \\
\text { manufacturing }\end{array}$ & 23.46 & 0.26 & 18.41 & 5.04 & 3.72 & 17.95 & 16.62 & 12.90 \\
\hline Other manufacturing & 18.83 & 2.68 & 16.98 & 1.85 & 1.29 & 6.66 & 6.10 & 4.81 \\
\hline $\begin{array}{l}\text { Electric and heat power } \\
\text { supply }\end{array}$ & 49.06 & 716.25 & 48.88 & 0.19 & 0.13 & 2.74 & 2.68 & 2.56 \\
\hline Gas production and supply & 5.40 & 8.78 & 5.40 & 0.00 & 0.00 & 0.00 & 0.00 & 0.00 \\
\hline Water production and supply & 3.10 & 0.22 & 3.10 & 0.00 & 0.00 & 0.00 & 0.00 & 0.00 \\
\hline Construction & 548.07 & 8.79 & 547.47 & 0.50 & 0.50 & 3.69 & 3.69 & 3.19 \\
\hline Transportation & 88.01 & 108.62 & 85.16 & 2.85 & 2.21 & 42.25 & 41.61 & 39.40 \\
\hline Retail and catering & 72.20 & 14.55 & 71.75 & 0.45 & 0.37 & 16.49 & 16.41 & 16.03 \\
\hline Other services & 243.60 & 21.22 & 240.05 & 3.54 & 3.14 & 15.55 & 15.15 & 12.01 \\
\hline Total & 2217.92 & 2066.30 & 2053.60 & 151.61 & 102.65 & 767.26 & 718.31 & 615.65 \\
\hline
\end{tabular}

\section{1) Results and analysis}

\section{a) Structure of the total embodied carbon emissions}

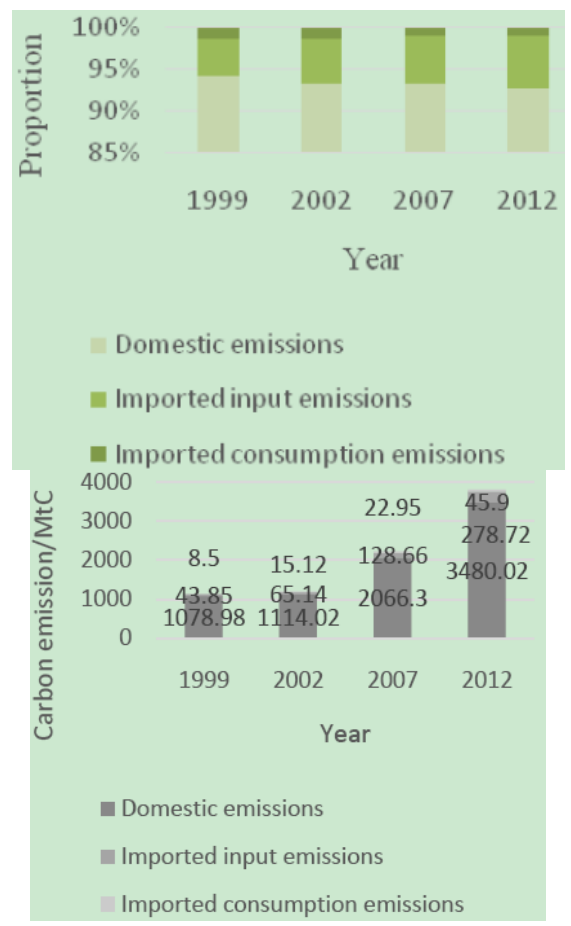

Fig. 1. Structure of the total embodied carbon emissions.
Fig. 1 shows the structure of the total embodied carbon. On the total, China's emissions (including domestic and foreign emissions) in 1999, 2002, 2007 and 2012 showed sustained growth, and its growth in 2001 has a significant change after China joined the WTO.

\section{b) Import and export embodied carbon emissions in each sector}

In 2012, the construction industry, other services, the electrical machinery and communication electronic equipment manufacturing industry, and the chemical industry are the most emissions in the total demand, totally accounting for $53.47 \%$ of the national total emissions. In contrast, non-metallic mining industry $(0.08 \%)$, water production and supply industry $(0.14 \%)$, coal mining and washing industry $(0.20 \%)$, gas production and supply industry $(0.24 \%)$ these four sectors are the smallest emissions. We can refer to more specific numerical results from the Table I.

\section{c) The composition and change of the total imports of departments}

In four years, the number of departments whose imported inputs emissions proportion of total imports is higher than the national average is respectively 14,13 and 13 , that is to say, these sectors have a higher proportion of imported emissions from the intermediate inputs. We can see the results from the following Table II. 
TABLE II: THE COMPOSITION OF THE DEPARTMENTS' TOTAL IMPORTS (\%)

\begin{tabular}{|c|c|c|c|c|c|c|c|c|}
\hline \multirow[t]{2}{*}{ Departments } & \multicolumn{4}{|c|}{ Imported inputs emissions and total import emissions } & \multicolumn{4}{|c|}{ Import re-export emissions and total import emissions } \\
\hline & 1999 & 2002 & 2007 & 2012 & 1999 & 2002 & 2007 & 2012 \\
\hline Agriculture & 54.47 & 56.76 & 71.72 & 75.63 & 9.18 & 10.26 & 19.5 & 22.87 \\
\hline Coal mining and dressing & 98.75 & 83.25 & 98.16 & 97.32 & 20.73 & 18.96 & 33.32 & 40.13 \\
\hline Petroleum \& gas & 105.34 & 95.15 & 99.49 & 98.43 & 25.3 & 25.02 & 35.63 & 37.81 \\
\hline Metal mining & 98.36 & 99.02 & 98.67 & 98.31 & 28.18 & 26.82 & 41.73 & 47.82 \\
\hline Nonmetal minerals mining & 97.47 & 95.52 & 99.88 & 103.41 & 14.52 & 14.15 & 23.9 & 24.5 \\
\hline Food and tobacco processing & 37.98 & 43.35 & 55.58 & 58.67 & 5.85 & 8.12 & 12.8 & 13.7 \\
\hline Textile industry & 86.50 & 86.44 & 96.84 & 94.17 & 34.64 & 40.34 & 55.72 & 68.92 \\
\hline Clothing, feather and leather & 32.95 & 38.18 & 52.93 & 61.67 & 10.41 & 14.69 & 19.82 & 20.53 \\
\hline Timber processing and furniture & 72.87 & 87.68 & 80.78 & 80.69 & 12.16 & 15.74 & 24.67 & 31.28 \\
\hline Paper printing & 90.00 & 89.45 & 96.30 & 92.45 & 19.75 & 22.35 & 30.41 & 38.07 \\
\hline $\begin{array}{l}\text { Petroleum, coking and nuclear } \\
\text { fuel processing }\end{array}$ & 100.70 & 98.05 & 96.95 & 94.36 & 18.42 & 22.24 & 31.93 & 37.84 \\
\hline Chemical industry & 91.97 & 91.82 & 95.59 & 97.88 & 23.69 & 27.04 & 36.66 & 42.43 \\
\hline Non-mental mineral products & 89.85 & 93.96 & 98.50 & 99.08 & 7.35 & 12.03 & 13.06 & 15.47 \\
\hline $\begin{array}{l}\text { Metal smelting and rolling } \\
\text { processing }\end{array}$ & 105.90 & 97.72 & 98.87 & 103.25 & 24.73 & 23.30 & 35.84 & 39.08 \\
\hline Metal products & 84.99 & 91.15 & 90.21 & 90.47 & 15.23 & 20.02 & 31.21 & 35.66 \\
\hline $\begin{array}{l}\text { General and special equipment } \\
\text { manufacturing }\end{array}$ & 60.50 & 57.49 & 60.72 & 63.67 & 11.17 & 12.18 & 19.69 & 22.35 \\
\hline $\begin{array}{l}\text { Transportation equipment } \\
\text { manufacturing }\end{array}$ & 56.78 & 60.93 & 59.42 & 57.88 & 9.97 & 12.35 & 15.05 & 17.84 \\
\hline $\begin{array}{l}\text { Electrical machinery and } \\
\text { communication electronics } \\
\text { manufacturing }\end{array}$ & 72.19 & 71.23 & 77.89 & 80.61 & 19.05 & 26.54 & 38.18 & 44.79 \\
\hline $\begin{array}{l}\text { Instrumentation and cultural } \\
\text { office machinery manufacturing }\end{array}$ & 86.53 & 80.64 & 76.52 & 77.49 & 17.79 & 17.64 & 26.30 & 27.38 \\
\hline Other manufacturing & 75.74 & 70.14 & 78.13 & 84.36 & 19.91 & 17.63 & 30.21 & 39.02 \\
\hline Electric and heat power supply & 93.81 & 85.47 & 92.80 & 97.69 & 20.66 & 20.94 & 31.60 & 35.86 \\
\hline Gas production and supply & 0.00 & 66.59 & 0.00 & 0.00 & 0.00 & 14.77 & 0.00 & 0.00 \\
\hline Water production and supply & 6.11 & 6.55 & 3.24 & 2.81 & 0.83 & 1.02 & 0.46 & 0.38 \\
\hline Construction & 84.89 & 81.21 & 85.32 & 86.10 & 15.20 & 15.36 & 17.16 & 18.95 \\
\hline Transportation & 70.44 & 66.01 & 60.00 & 52.33 & 15.02 & 15.36 & 17.16 & 16.87 \\
\hline Retail and catering & 37.09 & 38.40 & 40.76 & 41.55 & 6.46 & 7.81 & 11.26 & 13.45 \\
\hline Average & 85.68 & 81.30 & 84.86 & 83.29 & 19.45 & 22.10 & 32.29 & 39.07 \\
\hline
\end{tabular}

\section{CONCLUSION}

With the increasingly active foreign trade (especially after China joined the WTO), China's carbon emissions have increased year by year. Since China's imports come from different countries and regions, we analyze the imported embodied carbon of China and find that the average of total imports emissions which accounts for about $30 \%$ is for re-export demand, while the actual emissions for the import of domestic consumer demands account for about $75 \%$ of the total each year. Whether total import or actual import (excluding import and export emissions), electrical machinery and electronic communication equipment manufacturing industry, chemical industry, metal smelting and rolling processing industry, general special equipment manufacturing industry these four departments are most import emissions. From the point of the net balance of embodied carbon, China has always been a net country of embodied carbon emissions in international trade. Due to the efficiency of China's energy use and technological backwardness, the exports of carbon emissions of China is much higher than other countries, especially the year from 2005-2007. In all departments, metal smelting and rolling processing industry, fabricated metal products and transportation industry these three sectors are the fastest growing emissions of all.

\section{REFERENCES}

[1] N. Ahmad and A.W .Wyckoff, "Carbon dioxide emissions embodied in international trade of goods," OECD Working Paper, Paris, vol. 65, p. 15, Jan. 2003. 
[2] H. Min and W. Shilin, "The origin and progress of embodied carbon in foreign trade," Journal of Shanghai Business School, vol. 2, pp. 11-17, May 2010.

[3] R. Batra, H Beladi, and R. Frasca, "Environmental pollution and world trade," Ecological Economics. vol. 45, pp. 171-182, July 1998.

[4] G. Machado, R. Schaeffer, and E. Worrell, "Energy and carbon embodied in the international trade of Brazil: An input-output approach," Ecological Economics. vol. 39, pp. 409-415, May 2010.

[5] I. Mongelli, G. Tassielli, and B. Notarnicola, "Global warming agreements, international trade and energy/carbon embodiments: An input-output approach to the Italian case," Energy Policy, vol. 34, pp. 88-96, May 2006.

[6] J. Munksgard and K. Pedersen, " $\mathrm{CO}_{2}$ accounts for open economics: Produceror consumer responsibility?" Energy Policy, vol. 29, pp. 327-340, April 2001.

[7] G. P. Peters and E. G. Hertwich, " $\mathrm{CO}_{2}$ embodied in international trade with implication for global climate policy," Environment Science \& Technology, vol. 42, pp. 1401-1411, August 2008.

[8] J. H. Pan, J. Phillips, and Y. Chen, "China's balance of emissions embodied in trade: Approaches to measurement and allocation international responsibility," Oxford Review of Economic Policy, vol. 24, pp. 354-367, July 2008.

[9] L. N Moses, "The stability of interregional trading patterns and input-output analysis," American Economic Review. vol. 45, pp. 803-814, May 1955.

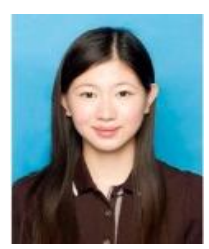

Zhonglin Sheng was born in June 1989 in China. She is a Ph.D student in management in 2016. In University of Science and Technology Beijing, Beijing, China. Her major is in environmental economics and risk management.

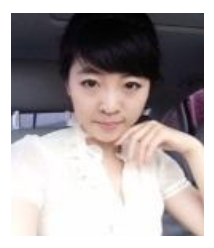

Yufei Xin was born in July 1987 in China. She is a Ph.D student in management in University of Science and Technology Beijing, Beijing, China.

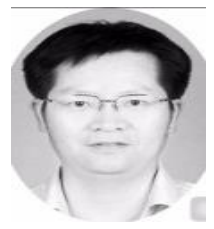

He Weida is the dean of the Department of Economics, University of Science and Technology Beijing, China. 